Chapman University

Chapman University Digital Commons

Education Faculty Articles and Research

College of Educational Studies

8-7-2017

\title{
"They Write Me Off and Don't Give Me a Chance to Learn Anything": Positioning, Discipline, and Black Masculinities in School
}

Quaylan Allen

Chapman University, qallen@chapman.edu

Follow this and additional works at: http://digitalcommons.chapman.edu/education_articles

Part of the African American Studies Commons, Curriculum and Instruction Commons, Curriculum and Social Inquiry Commons, Elementary and Middle and Secondary Education Administration Commons, Inequality and Stratification Commons, Race and Ethnicity Commons, and the Social and Philosophical Foundations of Education Commons

\section{Recommended Citation}

Allen, Q. (2017). “They write me off and don't give me a chance to learn anything”: Positioning, discipline, and black masculinities in school. Anthropology \& Education Quarterly, 48(3), 269-283. doi:10.1111/aeq.12199

This Article is brought to you for free and open access by the College of Educational Studies at Chapman University Digital Commons. It has been accepted for inclusion in Education Faculty Articles and Research by an authorized administrator of Chapman University Digital Commons. For more

information, please contact laughtin@chapman.edu. 


\section{"They Write Me Off and Don't Give Me a Chance to Learn Anything": Positioning, Discipline, and Black Masculinities in School}

\section{Comments}

This is a pre-copy-editing, author-produced PDF of an article accepted for publication in Anthropology \& Education Quarterly, volume 48, issue 3, in 2017 following peer review. The definitive publisher-authenticated version is available online at DOI: 10.1111/aeq.12199

\section{Copyright}

American Anthropological Association 

"They write me off and don't give me a chance to learn anything": Positioning, Discipline
and Black masculinities in school

Quaylan Allen

\title{
Chapman University
}

\begin{abstract}
This study examines the schooling of Black male students in a United States high school. Drawing upon positioning theory and student resistance literature, I describe how the students make meaning of the pathologizing positioning practices of the school, including how they resist and internalize dominant discourses about Black masculinity, and how their performances of particular masculinities within the school are met with surveillance, regulation and discipline. I argue that schools are locations where dominant ideologies of Black masculinities are imposed, contested and sometimes reproduced.
\end{abstract}

Keywords: Black males, student resistance, positioning theory, secondary education Running head: BLACK MALE RESISTANCE 


\section{Introduction}

The increasing visual documentation of the treatment of Black males by law enforcement and civilians has captured public attention by graphically exposing the endemic regulation and disregard of Black masculinities. The tragic and unjust circumstances that led to the deaths of Trayvon Martin, Jordan Davis, Jonathan Ferrell, Michael Brown, Eric Garner, Tamir Rice and Freddie Gray among others, helps us understand how Black masculinities are perceived, regulated, disciplined, and seemingly undervalued in U.S. society. Within a White hegemonic society, Black masculinities are a collection of practices viewed through a particular intersection of raced and gendered discursive practices that pathologize Black males as hypermasculine, deviant, hypersexual, intellectually inferior, and uneducable (Ferber 2007; Harris, 2006; hooks 2003; Majors and Billson 1992; Staples 1982). This racist ontology of Black masculinity limits the recognition of diverse Black masculine performances and ignores how Black males enact agency in responding to various structural barriers and dominant discourses about them.

Schools in particular are powerful but contested sites of cultural reproduction (Anyon 1980; Bourdieu and Passeron 1990; Bowles and Gintis 2002; Coleman 1987) that, in addition to contributing to inequitable economic stratification, also reproduce dominant ideologies (Althusser 1971; Collins 1971). Specifically, schools, and their institutional actors draw upon and contribute to dominant ideologies of Black male identity by positioning Black boys as culturally deficient, anti-intellectual, deviant, and intimidating (Howard et al. 2012; Ferguson 2000; Sewell 1997). For example, research examining school microsystems (e.g. relationships and interactions) consistently demonstrate the role that teachers' and administrators' racialized beliefs about Black male intelligence and deviance contribute to how Black boys experience racial microaggressions in school (Solórzano, Ceja, \& Yosso, 2000; Allen, 2013), are 
academically tracked into lower ability and special education programs (Ford et al. 2002; Harry and Klingner 2006; Kalogrides \& Loeb, 2013) and experience disproportionate discipline (Ferguson 2005; Lynn et al. 2010; McGrady and Reynolds 2013). These school climate, academic, and disciplining events then contribute to Black male social stratification, and how Black males are pathologized within popular discourse as culturally deficient and a "problem" that needs to be fixed (Frazier 1966; Howard 2013; Mauer 1999).

There is an impactful yet relatively small body of ethnographic research describing how Black boys respond to dominant pathologizing conceptions of their masculine identity and resist hegemonic school norms and processes (Carter 2008; Dance 2002; Ferguson 2000; hooks 2003; MacLeod 1987). However, more research is needed in this area with a particular focus on examining Black male agency, and how Black boys make meaning of their schooling experiences. As Hunter and Davis (1994) explain, discourses about Black males seem to rarely include the actual voices of Black males. In this paper I present narrative and observational data from a larger study of Black male students in a secondary school setting. The current paper focuses on the voices of four working-class students and how they make meaning of the pathologizing practices of the school. I present data describing how they both resist and internalize dominant positioning discourses about Black masculinity, as well as how their performances of particular masculinities of resistance are met with school disciplining events. An explanation of positioning theory and its relevance to the literature on Black male student resistance will be followed by an explanation of the research methodology. I will then present the findings and subsequently discuss how dominant ideologies of Black masculinity are imposed, contested and reproduced through the interplay of Black male agency and the positioning and disciplining practices of the school. 


\section{Positioning Theory and Black Male Resistance in School}

As ideological institutions, schools are locations where race and gender are socially constructed (Kimmel 2004; Martino 1999; Perea et al. 2000). Through the discursive practices of schools, Black males encounter dominant ideologies about their raced and gendered identities, and respond through a range of practices that adapt to or resist such dominant conceptions of their masculinity (Harper 2009; Noguera 2008; Whitehead and Barrett 2001). Positioning theory is useful in describing an aspect of this process as it concerns the historical and cultural processes, interactions, and practices that place individuals into different identity categories, roles, or narratives, and the way that individuals may take up such identities or reposition themselves in relation to imposed roles (Davies and Harré 1990; Harré et al. 2009; Holland and Leander 2004). These processes might occur through positioning events, which are instances when dominant ideologies are imposed (Holland and Lave 2001).

For instance, teachers of Black males, who are overwhelmingly White, middle-class and female, regularly draw upon dominant pathologizing discourses when thinking about, interacting with, and talking about their Black male students (Coopersmith 2009; Ladson-Billings 2006; Milner 2013). The cumulative effect of these positioning events contributes to the thickening (Holland and Lave 2001) of the socially constructed identities of Black boys. When Black boys encounter positioning events, they might take up dominant assumptions of their identity or reposition themselves as a way to push back against hegemonic discourses. How, when, and why Black boys reposition themselves varies and is dependent on context, but ultimately points to the agency of Black boys as they interact with the positioning events of the school. To this end, positioning theory seems to have relevance to the research literature on student resistance (Giroux 1983; McLaren 1999; Miron and Lauria 1998; Willis 1977) as they both point to the 
agency of individuals in contesting school dominance, though positioning theory has rarely been explicitly applied to Black male resistance to schooling.

Research on Black masculine student resistance generally describes a range of context specific behaviors, attitudes, and repositioning practices that Black males enact to varying degrees in response to both the stratifying nature and ideological dominance of schools. For example, as Black males recognize racial and class stratification in society, and thus question the benefits of formal schooling, some disengage from school and perform masculinities of academic indifference (Majors and Billson 1992). In doing so, they might downplay the behaviors associated with academic success (Fordham and Ogbu 1986; 1987; Solomon 1992) and might view adoption of the dominant White middle-class ideology of the school as incompatible with their own cultural capital and status positioning practices (Carter 2003; Dance 2002; Fordham 1996; Sewell 1997; Solomon 1992).

Additionally, because Black males are often mistreated in schools, academically tracked out of educational opportunities, and experience disproportionate surveillance and discipline (Gregory et al. 2010; Losen and Martinez 2013), there are cases in which Black males respond to such inequities and associated feelings of powerlessness by performing masculinities that outwardly reject the bourgeois behavioral norms of the school. They do so by enacting masculinities that assert power through school disruption, even when such disruption might come with a consequence (Dickar 2008; Ferguson 2000; Gillborn 1990; Solomon 1992). This type of resistance is often assumed to be self-defeating in that it confirms preconceived racist notions of Black masculinity by taking up an imposed identity position of deviance, and leads to the exclusion of Black boys from school. 
In other cases, Black males resist school ideological hegemony and display an emerging state of critical consciousness needed for social transformation. For instance, Black males might refuse the positioning practices of the school by performing more progressive Black masculinities that stand against racial domination and critique the processes and ideologies contributing to the overregulation, surveillance, and discipline of Black masculine performances (Caton 2012; Ferguson 2000; Fine 1991; Gillborn 1988; Mutua 2006). Furthermore, instead of opposing academic achievement and taking up an imposed deficit identity (e.g. anti-intellectual), Black males might reposition themselves by viewing achievement as a means to access power and as a political act of resistance against dominant denigrating assumptions of Black intelligence (Carter 2008; Warren 2005). This repositioning can be accomplished when Black males learn to navigate the politics of schooling by strategically accommodating certain middleclass expectations of school performance and behavior, while drawing upon Black cultural capital and community solidarity in order to maintain a sense of self-worth (Allen 2013; Carter 2006; Gayles 2005; Horvat and O'Connor 2006).

Still, the strength of schools' normalizing positioning discourses cannot be made light of, as it is not uncommon for Black males to internalize the pathologizing discourses of the school by explaining the consequences of certain Black masculine performances and academic outcomes using the school's achievement and individualistic ideologies. In internalizing this imposed position, Black males might downplay the structural barriers in their schooling and contribute to the school's deficit positioning by blaming themselves for their school failure (Dhondy et al. 1982; Ferguson 2000; MacLeod 1987). Considering the types of marginalization Black males experience in school, examining the resistance of Black boys means to not only 
examine the degrees of intent behind their behaviors, but also the structural and discursive contexts in which their masculine agency is enacted and limited.

\section{Methodology}

The findings presented in the study derive from an ethnographic study conducted with ten Black male youth and their families, at Central High School, a suburban school of over 2,000 students located in a large Western United States city. Data were collected during the 2008-2009 school year through various interview strategies and from documents and field observations that focused on interactions between and among students, teachers, and administrators and school policy outcomes. Central High School is a racially and economically diverse suburban school. At the time of the study, the student population was $29 \%$ Black, 28\% Asian, $19 \%$ Latino, $11 \%$ White, and 13\% Other; and almost half of the students qualified for a free or reduced-price lunch. The surrounding community consists of a large number of new tract and custom homes, apartments, retail shops, a community college, a new public library, and other public and private facilities (e.g., golf driving ranges, hospitals). The residents in the immediate neighborhood are racially diverse and largely middle class; however, the school is zoned to draw students from several neighboring communities that are socioeconomically diverse.

The students participated in two in-depth, semi-structured interviews and one photo elicitation interview (Allen 2012) that explored their educational biographies and how they made meaning of school opportunity, achievement and their social position as raced-gendered bodies. The parents and teachers of the students were each formally interviewed once regarding their views of the students' educational experiences. As a method of triangulation, the collective interviews were multivocal interpretations (Tobin, Wu, \& Davidson, 1989) of the same phenomenon and important to the discovery of meaning for each set of participants. Unstructured 
questions were used during casual interactions with the participants (Spradley, 1979) and took place during on-campus field observations. Over 300 hours of field observations were conducted with students and teachers in classrooms, hallways, cafeterias, teachers' lounge, and sporting events, among other school spaces. Interviews and observations were transcribed, coded, and analyzed using Erickson's (1986) qualitative interpretive approach. Finally, participants were provided with manuscript copies and asked for feedback on generated final themes as a method of member checking (Lincoln and Guba 1985). Previous publications from this study have examined the educational experiences of Black middle-class males, Black families' encounters with school-based racism, Black male achievement, and teacher ideologies (Allen 2013a, 2013b, 2015a, 2015b). The data presented in the current paper focus solely on four working-class Black males.

Researcher Subjectivity

As a college-educated Black male, and in my late twenties at the time of the study, I was both an insider and an outsider in relationship to the phenomena of study. I was an insider due to the racial and gender characteristics that I shared with the male participants. I also could be considered an insider due to my familiarity with the local community and school districts, having spent much of my youth living in the region. At the same time, I was considered an outsider due to my institutional role as a university researcher, my age, and the fact that I had not lived in the region for over a decade.

Considering my identity and position, I acknowledge the barriers to intersubjectivity; that is, anything that I document must be understood as a "partial truth" (Clifford 1986). Thus, I recognize the limitations of my own subjective interpretation and cannot assert disingenuously that my claims are completely neutral or objective. However, discourses about Black males seem 
to rarely include the voices of Black males (Hunter and Davis 1994), thus my intent in conducting research of this matter is to privilege the often-ignored voices of Black male youth, while also identifying the opportunities and barriers that contribute to their educational and social mobility.

Participants

The families presented in this paper possessed an array of cultural wealth but experienced various hardships related to their economic position. The families can be generally characterized economically as poor or working poor. Each family qualified for a free or reduced-cost lunch program, and only one of the mothers was employed at the time of the study. The parents held high educational aspirations for their sons and embraced the value of education. Nonetheless, considering the economic and racial barriers the mothers faced, it appears their educational expectations were also pragmatic. The parents had modest educational backgrounds, and most of their children had not finished high school themselves. Although a college education was desired, the parents were largely hopeful that the sons who participated in the study would, at minimum, get good grades and finish high school.

Garrett was a junior at the time of the study and had a passion and talent for visual arts. His ceramics teacher described him as meticulous in the classroom and believed that Garrett could make a career in art. He enjoyed working at his various after-school jobs. His mother described him as a sweet kid who struggled with being poor, wanting material goods but not always having the means to acquire them. She believed this was a major reason why Garrett enjoyed making money more than engaging in school.

Santonio had an outgoing personality and enjoyed the social environment of the school. His mother described him as self-sufficient and deeply concerned about the well-being of others. 
As a sophomore and social butterfly, Santonio invested his time in developing relationships with those around him. His English teacher commended his oratory skills, describing him as "having all the words" and that "he should be a car salesman."

Andre was quiet and thoughtful and his mother described him as a shy boy who often kept to himself. An introspective and artistic young man, his mother felt that he did not always apply himself in school. This sentiment was shared by his history teacher, who, although often displaying Andre's art in his classroom, feared that his academic potential would go to waste. A junior at the time of the study, Andre stated that he generally enjoyed school and had dreams of becoming an entrepreneur.

Dontay was the seventh of ten children. As one of the youngest and diminutive in size, his mother described him as having a Napoleon complex. He was a self-proclaimed street intellectual and hustler. As an outgoing and seemingly larger-than-life personality, Dontay, a senior, was well known on campus. He was extremely bright and intellectually gifted but spent a large portion of his high school career disengaged from school. Similar to Garrett, Dontay enjoyed making money and would regularly miss part of the school day to pick up work shifts as a valet at a local mall.

\section{"They Stereotype a Lot": Critiques to School Positioning Discourses of the School}

Central High School, like many high schools across the United States, struggles to meet the needs of their Black male students. The school is diverse and their records show disparities in Black male discipline, achievement scores, college readiness, and placements in gifted, upper ability, and special education programs. During the interviews, students discussed observations of their unequally differentiated schooling as Black males. In each case they described their interactions in the school and the daily experiences of racial microaggressions. They shared 
concerns about being misunderstood by teachers who relied on racial stereotypes to inform their interpretations of Black male behaviors. For instance, Andre provided examples of why he believes teachers misinterpret his behavior as defiant or anti-intellectual. He begins by explaining the importance of understanding behavior within context:

And so I feel the teachers don't strive to get to really know that person or really know where that person come from and that they could just be like acting out for something that they doing at home...Like, they expect me to, you know, come into class and don't be mad, be glad and everything, and they expect me to do my work sometimes regardless of what my mood is. So if I'm stressed out, they expect me to do that [work].

He continues his explanation of how his behaviors are misinterpreted by saying:

Teachers talk to you, like, they don't put you at the same level as your intelligence or I could say that they stereotype a lot. Like, okay, say if I wear saggy jeans, doo-rag, or something like that, they write me off and don't give me a chance to learn anything. Similarly, Dontay critiques the way racial stereotypes are used in the surveillance of Black masculinities in school:

Racism didn't disappear, it evolved with the times. You're being watched all the time. They see you and they see bad because you're Black. They see your skin color and they see gangster because you're Black. They're already stereotyping you off the get go. And because I was Black, they looked at me different, they watched me more.

In the absence of understanding Black male youth, and the context and intent in which certain masculinities are performed, teachers often draw upon dominant racial ideologies and stereotypes to inform their interactions with Black males (Coopersmith 2009; Gregory et al. 2010). Teachers might misinterpret the behaviors and style of Black boys as defiant, or 
physically and sexually intimidating, regardless of the intent (Ferguson 2005; Ferguson 2000; Monroe 2005). And as in the positioning events described, teachers may use particular Black male presentations of self to apply normalizing judgments of Black male academic ability, deviancy and sexuality.

Teacher perceptions of Black males not only influence the quality of their relationships with their students but also contribute to how Black males are excluded from learning opportunities. The students described the racialized exclusionary practices of their teachers, including being singled out in class and unfairly or excessively disciplined. For example, Santonio discussed a teacher who singled out Black students in class:

...but I honestly think that she might be a racist. I'm not the only one who thinks it. Every parent had a problem with that teacher. I mean she'd, I'd finish the work, and she'd tell me to work on something else, and other people are done with their work and they get to just sit there and talk. She singled a lot of [Black] kids out that way. In keeping with Santonio, Garrett explained, "Yeah, some teachers act like they can help everybody else, but they kind of shy away to help the Black students." Similarly, Andre echoed this sentiment, stating, "I'd say, like, that most of the Black kids would get, like, suspended or you know, like, be sent out of class, be on timeout." The suspension records at Central High School confirmed the young men's accounts of racialized discipline, as Black males were disproportionately referred to the front office and accounted for almost half of the school's suspensions.

The students in the present study appeared conscious of the role race played in their schooling as they critiqued how Black males were pathologically positioned as deviant and how assumptions of their deviancy contributed to poorer educational opportunities within the school. 
Still, despite their criticisms, it was also clear that the students internalized some of the pathologizing discourses about Black males. As other research has shown, it is not uncommon for Black males to both resist and accommodate the positioning discourses of the school in inconsistent and contradictory ways (Dhondy et al. 1982; Ferguson 2000; MacLeod 1987). "It's because of the way we live": Internalizing Positioning Discourses of the School

Like many students attending schools in the U.S., the young men saw school as a place for self-improvement and work preparation as well as an opportunity to improve their social standing. They all expressed a desire to use schooling toward these ends and an expectation to attend college. Andre explained how he views schooling:

The purpose of school is basically giving you a chance to be someone, like, basically, if you don't take it seriously, the whole world is going to gobble you up, basically. So what school really means to me is, like, if you grew up somewhere, there's a chance to come out of that and be something better.

To this end, despite their critiques of school racism, the students still adopted meritocratic and achievement orientations and believed school to be a place to "be something better." They also believed in the ideology of individualism, i.e., that they were responsible for their own success and failure. Recognizing school based racism while also embracing the achievement ideology of the school reflects the students' multidimensional attitudes toward education. Mickelson's (1990) research on Black adolescents describes how students hold both abstract and concrete attitudes towards education; the former is based on dominant ideology and the latter is based on raced, gendered and classed realities. Mickelson argues that regardless of the adoption of abstract attitudes, it is the concrete attitudes that inform educational achievement. Thus, the 
realities of race, gender and class barriers might inform educational success more so than the belief of meritocracy.

These divergent attitudes appear to be the case for Black males in the present study as each of them described the realities of school-based racism and struggled academically in school. However, when specifically asked about their academic performance, they often downplayed their concrete experiences with racism and blamed themselves. In some cases they cited individual impediments, such as their lack of effort or focus, while in other cases they spoke more broadly, using cultural impediments to explain their and other Black males' academic and behavioral performances. In these explanations, the young men seem to internalize dominant discourses of Black masculine identity that position them as culturally deficient.

Garrett described his own self-efficacy in a math class by explaining, "I just don’t like it. It confuses me. And once I don't like something, I just don't want to do it no more. I don't like math." Other students expressed their regret about not pushing themselves harder in their classes. In particular, each student pointed to his freshman year as a time during which he regretted his lack of effort. In this regard, Andre explained:

For high school, like for my freshman year, I shouldn't have messed around. I was doing what everybody else was doing. I wasn't a follower, but I wasn't really focused on school. I should have hit the ground running because, even though I didn't get in trouble my freshman year, I still played around and didn't do my work like I'm doing now. While personal effort was regularly cited as cause for their academic struggles, they also drew upon cultural explanations to explain their own struggles and the larger struggles of Black men in school. Dontay attributed his and other Black men's underachievement to the lack of discipline: 
It's because of the way we live, you know, it's the discipline. You got to have discipline, and, I mean, you don't need to be smart to get straight A's. I know it. I still don't get them because of the fact that I'm not really disciplined. I'm not mentally disciplined. Physically? I could go to the end of the earth. I could do whatever. But when it comes down to it, when it comes down to me sitting there and disciplining myself to do my homework instead of going out there to play basketball or going to the gym to lift weights? It's hard.

Santonio provided a similar explanation that emphasizes Black resistance to school endeavors: We tend to think that schooling is a waste of time because it's either redundant because we didn't pass it and we have to take it again, or we take it and we have to review it all over again and it's redundant and nobody wants to be around for it. And so they, or we, tend to slack off by either talking in class or passing notes or just ditching altogether.

Similar to other Black boys, the students in the present study internalized the abstract dominant ideology of the school through their adoption of an achievement and individualistic ideology (Ferguson 2000; Fine 1991; MacLeod 1987). This type of accommodation to school hegemonic norms downplays the material and racial barriers that may contribute to school performance and overemphasizes personal and cultural deficits. Further, in describing their academic struggles, the young men drew upon pathologizing positioning discourses of Black masculinity that characterize Black men as hypermasculine, hyperphysical, and hypersexual but also undisciplined and intellectually deficient. The saliency of these abstract and dominant ideologies in the students' narratives might point to the strength of the normalizing positioning discourses of the school, and the way such discourses limit their understanding of their masculinities and the structural barriers contributing to their educational outcomes. 


\section{"You don't have to do much to get sent to OCS": Resistance, Positioning and Discipline}

The students' discordant attitudes towards the schools' positioning discourses suggest that schools are contested locations in which dominant ideologies are imposed. The disciplining events of the school play a notable role in this process as they are "the primary means through which symbols of power and authority are perpetuated" (Noguera, 2008, pg. 96) and where certain masculinities are reproduced and regulated. Descriptions of the school's disciplining events were frequent in the narratives of the students. At Central High School, like many schools in the U.S., Black male bodies are highly surveilled, regulated and displaced.

During observations in their classrooms, the young men were generally engaged in learning activities and were contributors to classroom discourses. However, like many students in schools, the boys would at times disengage from classroom learning and tested the spatial, temporal, and behavioral norms of the school (Aggleton 1987; Willis 1977). Disruptive behaviors such as talking out of turn or side talk were common ways students at Central High contested teacher control strategies, but Black male behavior appeared to be disproportionately the focus of these strategies. When I was sitting near Andre, I noticed that most of the students in the classroom were at some point engaged in side talk, yet Black males were regularly displaced throughout the classroom or were sent outside. In this regard, I recorded the following events in my field notes:

Andre is sitting in the second row near the front of his Spanish class and has been chatting with his neighbor. They are discussing how they are going about buying and selling shoes through their peer networks. It is 15 minutes into the class and there is a consistent murmur of side talk among students. The teacher has asked Andre to quiet down twice already. Andre's counter to these requests is to keep an eye on the teacher 
and continue conversing with his neighbor based on the proximity of the teacher. The closer the teacher moves to him, the less he attempts to talk. The farther the teacher moves away from him, the more he talks. The teacher hands out a worksheet that students are expected to complete. Andre begins completing the worksheet but continues to talk to his neighbor about how they are going about buying and selling shoes through their peer networks. The teacher comes over and asks Andre's neighbor to move his desk farther to the right and work with someone else. This does not stop Andre and his neighbor from talking while they work. Ten minutes later, Andre raises his hand to request a completion stamp. The teacher checks his work, then explains that he has not completed the opposite side of the worksheet. Andre said he didn't know there was another side (which he missed because he was talking during the teacher's explanation). He begins to work on the other side of the worksheet, but shortly continues his conversation with his neighbor again. The teacher then comes over and moves Andre to the back of the room, where he completes his worksheet within the allotted time given for the assignment (Field notes, Dec. 16, 2008)

The classroom is often a space of regulation: Teachers decide who can talk, when to talk, and with whom. The classroom is also a contested space where students negotiate and manipulate teacher control strategies in various ways. The observation that is presented here highlights this interplay between student resistance and teacher control strategies and the way Black male bodies are regulated within the classroom. Furthermore, considering that Andre was one of many students engaging in side talk throughout the class period, the surveillance and regulation of his body might support his and the other participants' criticisms of being singled out in class and unfairly disciplined by teachers. 
Other forms of resistance were met with more severe punishment. Garrett, Andre, and Dontay all had been suspended from school on different occasions for breaking school rules. Their infractions included verbal confrontations with teachers, excessive texting in class, or oncampus fights. For instance, Garret shared an incident regarding his cell phone that led to his being suspended for two days. As a result of parent lobbying, the school district allows students to carry cell phones with them on campus. Cell phone use is regulated on campus through a subjective policy colloquially known as, "If I see it or hear it, I take it," although this did not stop students from finding clever ways to use their phones, knowing they were allowed to have them. Students were observed secretly texting by placing their backpacks on their desk or lap, and hiding their hand that held the phone inside the bag to text. Others held the phones underneath their desk and sent text messages while appearing to look straight ahead at the teacher. These were common student acts of subversion used to break up the banality of classwork, however, when one is caught, the act becomes subject to policing and discipline.

Like many students on campus, Garrett participated in this practice but had been caught using his phone. When teachers attempted to confiscate his phone, he would refuse to acquiesce. Garrett stated, "Like, and I used to get caught texting, and they try to take your phone, and I was, like, 'nope,' and then you get sent to the office for that and be suspended." Garrett had been suspended for getting caught with his phone and for willful defiance, i.e., refusing to give over his phone to authorities. His refusal to turn over his phone to school authorities highlights how particular school policies can encourage certain responses by Black boys and how these masculine performances are used against them. In this situation Garrett knows he is allowed to have his phone despite the school's attempt to regulate his use of it. When he attempts to protect his private property, his behavior is interpreted by school officials as an act of defiance to school 
authority and is met with the disciplining event of being suspended from school. This event symbolically asserts the power and authority of the school, but also excludes Garrett from learning opportunities and contributes to the school's discursive practices that reproduce the position of Black masculinities as defiant and deviant (Collins 2011; Ferguson 2000; Noguera 2008).

I asked Garrett about the phone incident, what he thought he could have done differently, and how he thought the principal could have handled his situation differently. He responded:

I mean, uh, I would have probably just been like, if they asked for the phone, just give it to them [but, if I were the principal, I would] try to talk to them after class or something. But I wouldn't just suspend somebody over a phone like that. It was less than, like, thirty seconds, but now I'm missing two days of school, and I'm missing the work. Like, if you miss a test, you can't turn a test in. You just get a zero on it. That will make your grade go down.

Garrett's response exhibits some accountability for his actions but also provides an alternative solution to the infraction that invokes the use of dialogue to resolve conflict in school as opposed to punitive measures. Furthermore, Garrett's argument also illuminates the larger problem of how school suspensions remove Black males from the classroom and reduce their opportunity to learn. Teachers who send students to either on- or off-campus suspension are required to provide assignments, homework, and alternative tests to the student in his or her absence. However, this rarely happens, and students who are suspended often find themselves behind in the class or missing important lectures and even tests. This of course, increases the likelihood that students who fall behind will engage in off-task behaviors that lead to being removed from the classroom. It appears then that the disciplinary practices of the school support 
its own existence by reproducing Black boys as delinquent, while also contributing to the positioning discourses of the school.

However, the boys in the study are not passive subjects and in some cases would take up an imposed position identity of Black masculine deviance as an attempt to access power. For many Black males in the school, including the young men in the present study, being sent to oncampus suspension (OCS) was a way to escape the volatile classroom environment. Thus, talking out in class or defying teacher control strategies were tactical acts of masculine resistance. Dontay explains this commonly used strategy:

OCS is really fun. It was, like, if you're not feeling your teacher or you're not really feeling your day, you don't have to do very much to go to OCS. You know, like [say], "Shut up, teacher." Take the ticket [indicating being sent to OCS], go inside there [OCS], and you just chill. Like, you don't have to be quiet, the security guard don't care. You can sit there and talk on your phone, listen to music, and just chill for like an hour and a half.

I then asked whether he had been assigned any kind of homework, to which he replied:

The teacher is supposed to give you class work, but if you're going to OCS, you're the type who says, "Give me my D minus and I'll be happy, I'm expecting to fail anyway." You know?

During a conversation with OCS supervisor, she explained that students who get caught in the cycle of disciplinary practices start to give up on school and simply wait to get formally pushed out of the system. This expectation certainly may be the case, considering the cumulative effect of discipline (Losen et al. 2014), although it also appears that Black males are participants in this process. In Dontay's case, he was able to manipulate school disciplinary practices by 
temporarily appropriating school positioning discourses of Black masculine deviancy. He then uses his cultural capital, which is his understanding of school rules, to manipulate the teacher's control strategies toward provoking his exclusion from the classroom and further appropriates the OCS room as a type of free and unregulated space where he could "just chill" (Akom 2007; McLaren 1999). Thus, from Dontay's perspective, his masculine performance allowed him to gain access to power within the moment and signify his capabilities to navigate an institution that seeks to exclude him. At the same time, these types of masculine performances came with consequences in that they confirmed preconceived racist notions of Black male deviancy, and led to the students repeated discipline and exclusion from school.

\section{Discussion}

Schools are institutions where hegemonic but contested ontologies of Black masculinities are imposed. Though the positioning discourses and events of the school, Black boys learn, critique and sometimes internalize how their masculinities are misinterpreted (Dance 2002; Golden 2014; MacLeod 1987; Sewell 1997). The boys in the present study pushed against the school discourses that positioned them as deviant and anti-intellectual, describing how race mediated how school officials misinterpreted their behaviors. In other instances, the boys seemed to take up dominant meritocratic discourses that downplay structural realities and position Black boys as intellectually and culturally deficient. These discordant attitudes toward their schooling seem to highlight a tension between the school's normalizing discourses that impose a dominant but limited understanding of Black masculinities, and the agency of Black males in attempting to resist or push against such discourses. Thus, as other research on student resistance has shown, school ideologies are not imposed deterministically but are contested in various ways (Miron and Lauria 1998; Solomon 1992; Willis 1977). 
Furthermore, when Black males do resist the marginalizing discourses and practices of the school, they are able access power in the moment, but find their bodies highly surveilled and regulated. When the students in this study disengaged from class or tested school norms, they resisted school not just as adolescent boys, but as Black boys. Their masculinities of resistance then were surveilled, disciplined and used against them in affirming a dominant ontology of Black masculine deviancy. Thus, the disciplining events of the school are powerful acts of symbolic violence that support the social construction and positioning discourses of Black masculinities in school.

Black masculinities however are indeed diverse, and involve a range of behaviors and attitudes (Jenkins and Clark-Hine 2001; Mutua 2006). The boys in the present study were sons, siblings, adolescents, creatives, entrepreneurs, and intellectuals among other descriptors, and embodied a range of masculine experiences. However, within the context of the school, it appears that Black masculinities are limited in that despite the diversity of Black male performances, it is certain Black masculinities that are recognized and acknowledged more than others. For Black males operating within a constant discourse of deviancy, it is their masculinities of resistance that are most recognized and responded to by school authority. The student interview data seemed to attest to this, as encounters with school racism and disciplining events were prominent in their narratives. Furthermore, it is also possible that the limited range of masculinities Black males are recognized for in the school might contribute to the way students take up or appropriate discourses of Black male deviancy in order to access power within a marginalizing institution.

Finally, the narrative data presented in this paper highlighted a progressive Black masculinity of resistance, one that schools typically do not acknowledge. The Black males 
critiqued the positioning discourses of the school and called out the racialized practices of teachers and administrators. By identifying how race mediated the misinterpretation of their masculinities and the surveillance of their bodies, they performed a progressive Black masculinity that stands against the structure of racism (Mutua 2006). These repositioning discourses are a threat to the colorblind ideology of the school that seeks to downplay racial and other structural barriers that marginalize Black males. However, as a progressive Black masculinity of resistance, the counter-stories of Black males that push against marginalizing positioning discourses about them provide insight into possibilities towards school transformation (Carter 2008; Miron and Lauria 1998).

\section{Implications}

The narratives of the students provided insights towards the improvement of Black male school outcomes. Specifically, school disciplinary policies and practices seem to be an area of needed reform. As Black males are disproportionally disciplined, schools might consider revising their discipline policies. This might include developing teams to examine discipline data for race and gender overrepresentation, identifying the impact of particular discipline policies on student population groups, and work to provide appropriate interventions. Schools might also consider partnering with students, parents, and communities to review and revise their discipline code to clearly define offense categories. For example, willful defiance is a highly subjective offense, and like the students in the present study, Black masculinities are regularly misinterpreted as defiant and are disproportionally disciplined under this offense category (California Department of Education 2012).

Relatedly, schools should consider applying developmentally appropriate, context specific consequences, and emphasize prevention oriented and restorative practices. As in the 
current study, when Black males are removed from the classroom, they miss out on important instructional time. Thus it is critical to reduce the amount of time that Black males are removed from the classroom, and when students are removed, continue to provide quality instruction to reduce the negative effect that school discipline has on other student outcomes (e.g. disengagement, recidivism, drop out) (Losen et al. 2014; Morgan et al. 2014).

Finally, the young men shared stories of being misunderstood, stereotyped, and marginalized by their teachers. The majority of educators working with Black males are White, middle class, and female (Coopersmith 2009), many of which have had little meaningful interaction with students of color prior to entering the profession (Ladson-Billings 2000), and may draw upon deficit discourses in interacting with their Black male students. Such deficit views of Black masculinities should be countered with anti-deficit approaches to thinking about, understanding, and working with Black males. More research should qualitatively highlight the range of Black male gendered and sexual identities in schools, and how the intersection of such identities might be supported or suppressed by school policies and practices. Additionally, educator preparation coursework should provide an examination of factors that contribute to Black male academic engagement and success (Harper 2012; Ladson-Billings 1994; Wilson et al. 2013). This could include a more complex understanding and recognition of diverse Black masculinities, an examination of the intent and contextual factors that influence the performance and interpretation of Black male behaviors, and the school conditions needed for Black males to access education as a tool for power (Allen 2013; Casella 2003; Gayles 2005; Harper 2012; Howard and Reynolds 2008; Milner 2007).

Notes 
Acknowledgements. I want to thank Drs Rachel Lambert and Noah Golden for their initial feedback on the manuscript. I would also like to thank the reviewers and editors for their valuable feedback, which greatly improved the paper. 


\section{References}

Aggleton, Peter

1987 Rebels Without a Cause. London: Falmer.

Akom, A. A.

2007 Free Spaces: Excavating Race, Class, and Gender among Urban Schools and Communities. International Journal of Qualitative Studies in Education (QSE) 20(6):611616.

Althusser, Louis

1971 Lenin and Philosophy and Other Essays. London: New Left Books.

Anyon, Jean

1980 Social Class and the Hidden Curriculum of Work. Journal of Education 162(1):67-92.

Allen, Quaylan

2012 Photographs and stories: Ethics, benefits and dilemmas of using participant photography with black middle-class male youth. Qualitative Research, 12, 443-458.

2013a Balancing school and cool: Tactics of resistance and accommodation among black middle-class males. Race Ethnicity and Education, 16, 203-224.

2013b. "They think minority means lesser than": Black middle-class sons and fathers resisting microaggressions in the school. Urban Education, 48, 171-197.

2015a. "I'm trying to get my a": Black male achievers talk about race, school and achievement. The Urban Review, 47, 209-231.

2015b. Race, culture and agency: Examining the ideologies and practices of U.S. Teachers of Black male students. Teaching and Teacher Education, 47, 71-81

Bourdieu, Pierre, and Jean-Claude Passeron 
1990 Reproduction in Education, Society, and Culture. R. Nice, trans. Newbury Park, CA: Sage.

Bowles, Samuel, and Herbert Gintis

2002 Schooling in Capitalist America Revisited. Sociology of Education 75(2):1-18.

California Department of Education

2012 Expulsion and Suspension Data. Sacramento, CA: California Department of Education. Carter, Dorinda

2008 Achievement as Resistance: The Development of a Critical Race Achievement Ideology among Black Achievers. Harvard Educational Review 78(3):466-569.

Carter, Prudence

2003 "Black" Cultural Capital, Status Positioning, and Schooling Conflicts for Low-Income African American Youth. Social Problems 50(1):136-155.

2006 Straddling boundaries: Identity, culture, and school. Sociology of Education 79(4):304328.

Casella, Ronnie

2003 Zero Tolerance Policy in Schools: Rationale, Consequences, and Alternatives. Teachers College Record 105(5):872-892.

Caton, Marcia Theresa

2012 Black Male Perspectives on Their Educational Experiences in High School. Urban Education 47 (6):1055-1085.

Clifford, James

1986 Partial Truths. In Writing Culture, James Clifford and George Marcus, eds. Pp. 1-26. Santa Fe, NM: School of American Research. 
Collins, Kathleen M.

2011 Discursive Positioning in a Fifth-Grade Writing Lesson: The Making of a "Bad, Bad Boy." Urban Education 46(4):741-785.

Collins, Randall

1971 Functional and Conflict Theories of Educational Stratification. American Sociological Review 36(6):1002-1019.

Coopersmith, Jared

2009 Characteristics of Public, Private, and Bureau of Indian Education Elementary and Secondary School Teachers in the United States: Results From the 2007-08 Schools and Staffing Survey (NCES 2009-324). Washington, DC: U.S. Department of Education, National Center for Education Statistics, Institute of Education Sciences.

Dance, Lory Janelle 2002 Tough Fronts: The Impact of Street Culture on Schooling. New York: Routledge. Davies, Bronwyn, and Rom Harré 1990 Positioning: The discursive production of selves. Journal for the Theory of Social Behaviour 20(1):43-63.

Dhondy, Farrukh, Barbara Beese, and Leila Hassan

1982 The Black Explosion in British Schools. London: Race Today.

Dickar, Maryann

2008 Corridor Cultures: Mapping Student Resistance at an Urban High School.

New York: University Press.

Erickson, Frederick

1986 Qualitative Methods in Research on Teaching. In Handbook of Research on Teaching, 
Merlin C. Wittrock, ed. Pp. 119-161. New York: MacMillan

Ferber, Abby

2007 The construction of black masculinity: White supremacy now and then. Journal of Sport and Social Issues, 31, 11 - 24.

Ferguson, Ann Arnett

2000 Bad Boys: Public Schools in the Making of Black Masculinity. Ann Arbor: The University of Michigan Press.

Ferguson, Ronald

2005 Teachers' Perceptions and Expectations and the Black-White Test Score Gap. $\underline{I n}$

Educating African American Males: Voices from the Field, O. S. Fashola, ed. Pp. 347414. Thousand Oaks, CA: Corwin Press.

Fine, Michelle

1991 Framing Dropouts: Notes on the Politics of an Urban Public High School. Albany: State University of New York Press.

Ford, Donna, John Harris III, Cynthia A. Tyson, and Michelle Frazier Trotman 2002 Beyond Deficit Thinking: Providing Access for Gifted African American Students. Roeper Review 24(2):52-58.

Fordham, Signithia

1996 Blacked Out: Dilemmas of Race, Identity, and Success at Capital High. Chicago: The University of Chicago Press.

Fordham, Signithia, and John Ogbu

1986 Black Students' School Success: Coping with the Burden of Acting White. The Urban Review 1 (3):176-206. 
Frazier, Edward F.

1966 The Negro Family in the United States. Chicago: The University of Chicago Press.

Gayles, Jonathan

2005 Playing the Game and Paying the Price: Academic Resilience among Three HighAchieving African American Males. Anthropology \& Education Quarterly 36(3):250264.

Gillborn, David A

1988 Ethnicity and Educational Opportunity: Case Studies of West Indian Male-White

Teacher Relationships. British Journal of Sociology of Education 9(4):371-385.

1990 "Race," Ethnicity and Education: Teaching and Learning in Multi-Ethnic Schools. Key

Issues in Education. London, UK. Unwin and Hyman.

Giroux, Henry

1983 Theories of Reproduction and Resistance in the New Sociology of Education: A Critical Analysis. Harvard Educational Review 53(3):257-293.

Golden, Noah Asher

2014 'In a position i see myself in:' Young men of color (re)negotiating educational identities.

75, ProQuest Information \& Learning.

Gregory, Anne, Russell Skiba, and Pedro Noguera

2010 The Achievement Gap and the Discipline Gap: Two Sides of the Same Coin?

Educational Researcher 39(1):59-68.

Harper, Shaun R. 
2009 Niggers no more: a critical race counternarrative on Black male student achievement at predominantly White colleges and universities. International Journal of Qualitative Studies in Education $22(6): 697-712$

Harper, Shaun R

2012 Black Male Student Success in Higher Education: A Report from the National Black Male College Achievement Study. Philadelphia: University of Pennsylvania, Center for the Study of Race and Equity in Education.

Harré, Rom, Fathali M. Moghaddam, Tracey Pilkerton Cairnie, Daniel Rothbart, and Steven R. Sabat

2009 Recent Advances in Positioning Theory. Theory \& Psychology 19(1):5-31.

Harris, Keith

2006 Boys, boyz, bois: An ethics of black masculinity in film and popular media, New York \& London, Routledge.

Harry, Beth, and Janette Klingner

2006 Why are so Many Minority Students in Special Education? Understanding Race and Disability in Schools. New York: Teachers College Press.

Holland, Dorothy, and Jean Lave

2001 History in person: An introduction. In History in person: Enduring struggles, contentious practice, intimate identities, eds Holland, D and Lave, J, 3-33. Santa Fe, NM: School of American Research Press.

Holland, Dorothy, and Kevin Leander

2004 Ethnographic Studies of Positioning and Subjectivity: An Introduction. Ethos (32)2:127-139. 
hooks, bell

2003 We Real Cool: Black Men and Masculinity. New York: Routledge.

Horvat, Erin McNamara, and Carla O'Connor, eds.

2006 Beyond Acting White: Reframing the Debate on Black Student Schievement. Oxford, UK: Rowman \& Littlefield.

Howard, Tyrone C

2013 How Does It Feel to Be a Problem? Black Male Students, Schools, and Learning in Enhancing the Knowledge Base to Disrupt Deficit Frameworks. Review of Research in Education 37(1):54-86.

Howard, Tyrone C., Terry K. Flennaugh, and Clarence L. Terry Sr.

2012 Black males, social imagery, and the disruption of pathological identities: Implications for research and teaching. Educational Foundations 26 (1):85-102.

Howard, Tyrone C., and Rema Reynolds

2008 Examining Parent Involvement in Reversing the Underachievement of African American Students in Middle-Class Schools. Educational Foundations 22(1-2):79-98.

Hunter, Andrea, and James Earl Davis

1994 Hidden voices of Black men: The meaning, structure, and complexity of manhood. Journal of Black Studies 25, no. 1: 20-40.

Jenkins, Earnestine, and Darlene Clark-Hine

2001 A Question of Manhood: A Reader in U.S. Black Men's History and Masculinity, The 19th Century: From Emancipation to Jim Crow. Bloomington and Indianapolis: Indiana University Press.

Kalogrides, Demetra, and Susanna Loeb 
2013 Different teachers, different peers: The magnitude of student sorting within schools. Educational Researcher, 42(6), 304-316.

Kimmel, Michael

2004. The gendered classroom. In The gendered society, 159 - 79. Oxford: Oxford University Press.

Ladson-Billings, Gloria

1994 The Dreamkeepers: Successful Teachers of African American Children. San Francisco: Jossey-Bass.

2000 Fighting for Our Lives: Preparing Teachers to Teach African American Students. Journal of Teacher Education 51(3):206-214.

2006 It's not the culture of poverty, it's the poverty of culture: The problem with teacher education. Anthropology \& Education Quarterly 37, no. 2: 104-09.

Lincoln, Yvonna S., and Egon G. Guba

1985 Naturalistic Inquiry. Beverly Hills, CA: Sage.

Losen, Daniel J., D. Hewitt, and I.A. Toldson

2014 Eliminating Excessive and Unfair Exclusionary Discipline in Schools Policy Recommendations for Reducing Disparities. Bloomington, IN: The Equity Project at Indiana University.

Losen, Daniel J., and Tia Elena Martinez 2013 Out of School \& Off Track: The Overuse of Suspensions in American Middle and High Schools. Civil Rights Project/Proyecto Derechos Civiles.

Lynn, Marvin, Jennifer Nicole Bacon, Tommy L. Totten, Thurman L. Bridges, and Michael E. Jennings 
2010 Examining Teachers' Beliefs about African American Male Students in a LowPerforming High School in an African American School District. Teachers College Record 112(1):289-330.

MacLeod, Jay

1987 Ain't No Makin' It: Aspirations and Attainment in a Low-Income Neighborhood. Boulder, CO: Westview Press.

Majors, Richard, and Janet Mancini Billson

1992 Cool pose: The dilemmas of Black manhood in America. New York: Touchstone.

Martino, Wayne

1999. "Cool Boys', 'Party Animals', 'Squids' and 'Poofters': Interrogating the Dynamics and Politics of Adolescent Masculinities in School. British Journal of Sociology of Education 20 (2):239-63.

Mauer, Marc

1999 Crisis of the Young African American Male and the Criminal Justice System.

Washington, DC: The Sentencing Project.

McGrady, Patrick B., and John R. Reynolds

2013 Racial Mismatch in the Classroom: Beyond Black-White Differences. Sociology of Education 86(1):3-17.

McLaren, Peter

1999 Schooling as a Ritual Performance: Toward a Political Economy of Educational Symbols and Gestures. 3rd edition. Lanham, MD: Rowman \& Littlefield. Mickelson, Roslyn Arlin 
1990. The attitude-achievement paradox among Black adolescents. Sociology of Education 63 (1):44-61.

Milner IV, H. Richard

2007 African American Males in Urban Schools: No Excuses-Teach and Empower. Theory into Practice 46(3):239-246.

Milner IV, H. Richard

2013. Analyzing Poverty, Learning, and Teaching Through a Critical Race Theory Lens. Review of Research in Education 37 (1):1-53

Miron, Louis F., and Mickey Lauria

1998 Student Voice as Agency: Resistance and Accomodation in Inner-City Schools. Anthropology and Education Quarterly 29(2):189-213.

Monroe, Carla R

2005 Why are "bad boys" always Black? Causes of disproportionality in school discipline and recommendations for change. The Clearing House 79 (1):45-50.

Morgan, Emily, Nina Salomon, Martha Plotkin, and Rebecca Cohen

2014 The School Discipline Consensus Report: Strategies from the Field to Keep Students Engaged in School and Out of the Juvenille System. New York: The Council of State Governments Justice Center.

Mutua, Athena D.

2006 Theorizing progressive Black masculinities. In Progressive Black masculinities, ed. Mutua, AD, 3-42. New York: Routledge.

Noguera, Pedro A. 
2008 The Trouble with Black Boys: ....and other reflections on race, equity, and the future of public education. San Francisco: Josey-Bass.

Perea, Juan F., Richard Delgado, Angela Harris, and Stephanie Wildman

2000. Race and races: Cases and resources for a diverse America. St. Paul, Minn: West

Group.

Sewell, Tony

1997 Black Masculinities and Schooling. Stoke on Trent, UK: Trentham Books.

Solomon, R. Patrick

1992 Black Resistance in High School: Forging a Separatist Culture. Albany: State University of New York Press.

Solorzano, Daniel, Miguel Ceja, and Tara Yosso

2000 Critical Race Theory, Racial Microaggressions, and Campus Racial Climate: The experiences of African American college students." The Journal of Negro Education 69 $(1 / 2): 60-73$.

Spradley, James

1979. The Ethnographic Interview. New York: Holt, Rinehart and Winston.

Staples, Robert

1982 Black masculinity: The Black male's role in American society. San Francisco: The Black Scholar Press.

Tobin, Joseph J., David Y.H. Wu, and Dana H. Davidson

1989 Preschool in Three Cultures: Japan, China, and the United States. New Haven and London: Yale University Press.

Warren, Simon 
2005 Resilience and Refusal: African-Caribbean Young Men's Agency, School Exclusions, and School-Based Mentoring Programmes. Race Ethnicity and Education 8(3):243-259. Willis, Paul E.

1977 Learning to Labour. Farnborough, England: Saxon House.

Wilson, Camille M., Tyron M. Douglas, and Christine W. Nganga

2013 Starting with African American Success: A Strength Based Approach to Transformative Educational Leadership. In Handbook of Research on Educational Leadership for Equity and Diversity, Linda Tillman and James

J. Scheurich, ed. Pp. 111-113. New York: Routledge.

\section{Biography}

Quaylan Allen is an assistant professor in the College of Educational Studies at Chapman University. His research focuses on race, class and gender equity in educational policy and practice, Black male educational outcomes, Black masculinities and visual methodologies. He can be reached at qallen@chapman.edu. 